Research Paper

\title{
Microbiological aspects of the biofilm on wooden utensils used to make a Brazilian artisanal cheese
}

\author{
Éder Galinari*,1 ${ }^{*}$ Juliana Escarião da Nóbrega ${ }^{2}$, Nélio José de Andrade ${ }^{2}$, \\ Célia Lúcia de Luces Fortes Ferreira ${ }^{2}$ \\ ${ }^{1}$ Departamento de Microbiologia, Universidade Federal de Viçosa, Viçosa, MG, Brazil. \\ ${ }^{2}$ Departamento de Tecnologia de Alimentos, Universidade Federal de Viçosa, Viçosa, MG, Brazil.
}

Submitted: January 27, 2013; Approved: September 9, 2013.

\begin{abstract}
The artisanal Minas cheese is produced from raw cow's milk and wooden utensils were employed in its manufacture, which were replaced by other materials at the request of local laws. This substitution caused changes in the traditional characteristics of cheese. Due to the absence of scientific studies indicating the microbial composition of biofilms formed on wooden forms, tables and shelves used in these cheese production, the present work evaluated the counts of Staphylococcus aureus, Escherichia coli, coliforms at $32{ }^{\circ} \mathrm{C}$, yeasts, presumptive mesophilic Lactobacillus spp. and Lactococcus spp. in these biofilms, milk, whey endogenous culture and ripened cheese in two traditional regions: Serro and Serra da Canastra. Also, we checked for the presence of Salmonella sp. and Listeria monocytogenes in the ripened cheeses. The ultra structure of the biofilms was also assessed. Counts above legislation $(>2 \log \mathrm{cfu} / \mathrm{mL})$ for the pathogens evaluated were found in milk samples from both regions. Only one shelf and one form from Serro were above limits proposed $\left(5 \mathrm{cfu} / \mathrm{cm}^{2}\right.$ for $S$. aureus and E. coli and $25 \mathrm{cfu} / \mathrm{cm}^{2}$ for coliforms) in this study for contaminants evaluated. In Canastra, few utensils presented safe counting of pathogens. There was no Salmonella sp. and Listeria monocytogenes in the cheeses after ripening. Thus, the quality of the cheese is related to improving the microbiological quality of milk, implementation and maintenance of good manufacturing practices, correct cleaning of wooden utensils, and not its replacement.
\end{abstract}

Key words: biofilm, artisanal minas cheese, lactic acid bacteria, Serro, Serra da Canastra.

\section{Introduction}

Wood has been historically used in manufacturing utensils for making food such as vinegar (Solieri and Giudici, 2008), cider (Del Campo et al., 2003) and cheese, especially those with Protected Designation of Origin (PDO) status commercialized in European countries (Casalta et al., 2009; Mariani et al., 2007; Lortal et al., 2009).

In the manufacturing process, artisanal Minas cheese a traditional Brazilian cheese, made from raw cow's milk added rennet and whey endogenous culture (EC) comes into contact with wooden forms and tables during shaping, manual pressing and standing on wooden shelves for ripening (EMATER, 2004). The accumulation of organic matter in these utensils, among which proteins, carbohydrates and other compounds present in the milk, contributes to biofilm formation (Capdeville and Nguyen, 1990; Trulear and Characklis, 1982). The biofilm on utensils in the environment of cheese dairies is commonly formed by microbial components from the milk microbiota, such as yeasts and lactic acid bacteria ( $\mathrm{LAB})$, and also by microorganisms in the air and on the hands of cheese makers, such as filamentous fungi and pathogens. This biofilm can detach from the surface of wooden utensils becoming part of the EC microbiota ("pingo" that means drop) that will be consequently present in the cheese contributing to its ripening (Lortal et al., 2009). The pingo is collected daily after cheese production and remains refrigerated until the next batch. Laws of the State of Minas Gerais - the Brazilian state that produces 
this cheese - established that the wooden forms and tables were replaced by other materials (Minas Gerais, 2002a) and directed cheese makers to the standards of good manufacturing practices (GMP). Wooden forms were replaced by polypropylene or high density polyethylene forms, while wooden tables were substituted for slate or stainless steel. The replacement of wooden utensils by other materials changed the characteristics of the cheese. According to cheese makers, these new materials do not contribute to the syneresis of cheese, affecting the traditional flavor and texture. Furthermore, European studies indicate that the biofilm formed on wooden utensils have a role in the characteristics of ripened cheese that have PDO, such as Ragusano (Licitra et al., 2007; Lortal et al., 2009) and Reblochon de Savoie (Mariani et al., 2007).

The ways of manufacturing artisanal Minas cheese in two traditional producing regions (Serro and Serra da Canastra) are similar for milking and adding EC and rennet to milk. During shaping, the cheese makers in Serro press the curd inside the forms manually. On the other hand, in Canastra, the curd is placed inside tissues that aid in pressing. For this reason, the cheese produced in $\mathrm{Ca}-$ nastra initially have lower moisture content than that from Serro, thus Canastra cheese needs more time to ripening, as verified by Dores (2007). In the traditional method, after shaping, artisanal Minas cheese is placed on wooden shelves for ripening (Minas Gerais, 2002b). During this process, different physical and chemical changes such as reduction of $\mathrm{pH}$ (Beuchat and Golden, 1989), reduced redox potential (Crow et al., 1995) and decrease in water activity (Brown, 1976) restrict pathogen growth and allow the development of LAB that are better adapted to these conditions. At different moments, LAB and yeasts originating from the EC and/or biofilm from wooden utensils produce enzymes, organic acids and other antimicrobial compounds such as peptides and bacteriocins that aid in product safety (González et al., 2007). In addition, these modifications are essential for defining the aroma, flavor and texture of the cheese.

Since wooden tables and forms have been removed from the production of artisanal Minas cheese, which has subsequently altered its characteristics, and given the inexistence of scientific studies indicating the composition of microbial biofilms formed on these utensils, the objectives of this study were to get insights and present an overview of the microbial situation of wooden utensils by pathogen enumerations, and also enumeration of microorganisms involved on ripening of the artisanal Minas cheese like yeasts and the two principal genera of LAB found in these cheese mesophilic Lactobacillus spp. and Lactococcus spp. It were also evaluated the counts of these microorganisms on milk, EC and ripened cheese, as well as checking the ultra structure of the utensils biofilm.

\section{Materials and Methods}

\section{Milk, endogenous culture, cheese and biofilm sampling}

The number of utensils sampled represents the remaining wooden utensils still in use for artisanal Minas cheese making while the other producers have already replaced their utensils. These utensils are used and washed daily with water and have been used at least for five years.

Samples to evaluate biofilm on wooden utensils were obtained by the swab method (APHA, 2001), delimiting the sampling area with a sterile template of $10 \mathrm{~cm} \times 10 \mathrm{~cm}$ dimensions to collect on the shelves and tables and $2 \mathrm{~cm} \mathrm{x}$ $2 \mathrm{~cm}$ on the forms. Samples were collected from the surfaces of three tables, forms and shelves in Serro region, and three tables and shelves in Serra da Canastra region (Figures $1 \mathrm{~A}$ and $\mathrm{B}$ ). In the Serra da Canastra are no longer used wooden forms. The same microbial groups accessed in the biofilms were evaluated in three samples of milk before addition of EC, three samples of EC and ripened cheese in each region. The samples of milk and EC collected were the same used in the manufacture of cheeses evaluated. For each table it was sampled three areas of $100 \mathrm{~cm}^{2}$ and plated separately to evaluate the biofilm, a sample being taken from the central portion and two others from their extremities. The average of the counts from three points was obtained. A sample of $100 \mathrm{~cm}^{2}$ was taken from each shelf. A swab was used to collect four samples of $4 \mathrm{~cm}^{2}$ from each form. After sampling, each swab was placed in a flask containing $10 \mathrm{~mL}$ of $0.12 \%$ phosphate buffer solution, sterilized by autoclaving $\left(121{ }^{\circ} \mathrm{C}\right.$ for $\left.15 \mathrm{~min}\right)$, labeled and then stored on ice until the time of microbiological evaluations. Aliquots of $1 \mathrm{~mL}$ of each biofilm sample was diluted in $9 \mathrm{~mL}$ of $0.12 \%$ phosphate buffer, followed by serial decimal dilutions before plating in depth in the media described below.

\section{Microbiological analysis}

One-mL aliquots of milk and $\mathrm{EC}$ were diluted in $9 \mathrm{~mL}$ of $0.12 \%$ phosphate buffer solution, followed by serial decimal dilutions before plating. Portions of $25 \mathrm{~g}$ were taken from each ripened cheese for homogenization in $225 \mathrm{~mL}$ of $0.12 \%$ phosphate buffer solution using Stomacher 400 Bagmixer $^{\circledR}$ (Model VW, France) for 2 min at low speed. Serial decimal dilutions were made in samples previously homogenized before plating in depth.

The microorganisms quantified were: total aerobic mesophiles, yeasts, presumptive mesophilic Lactobacillus spp. and Lactococcus spp., Staphylococcus aureus, Escherichia coli and coliforms at $32{ }^{\circ} \mathrm{C}$ (designated here simply as coliforms). Aerobic mesophiles were grown on plate count agar (Difco, Lawrence, Kansas, USA) incubated at $30{ }^{\circ} \mathrm{C}$ for $48 \mathrm{~h}$. Yeasts were counted after aerobic incubation at $28{ }^{\circ} \mathrm{C}$ for 5 days on potato dextrose agar (Difco, Lawrence, Kansas, USA). Mesophilic Lactobacillus spp. 


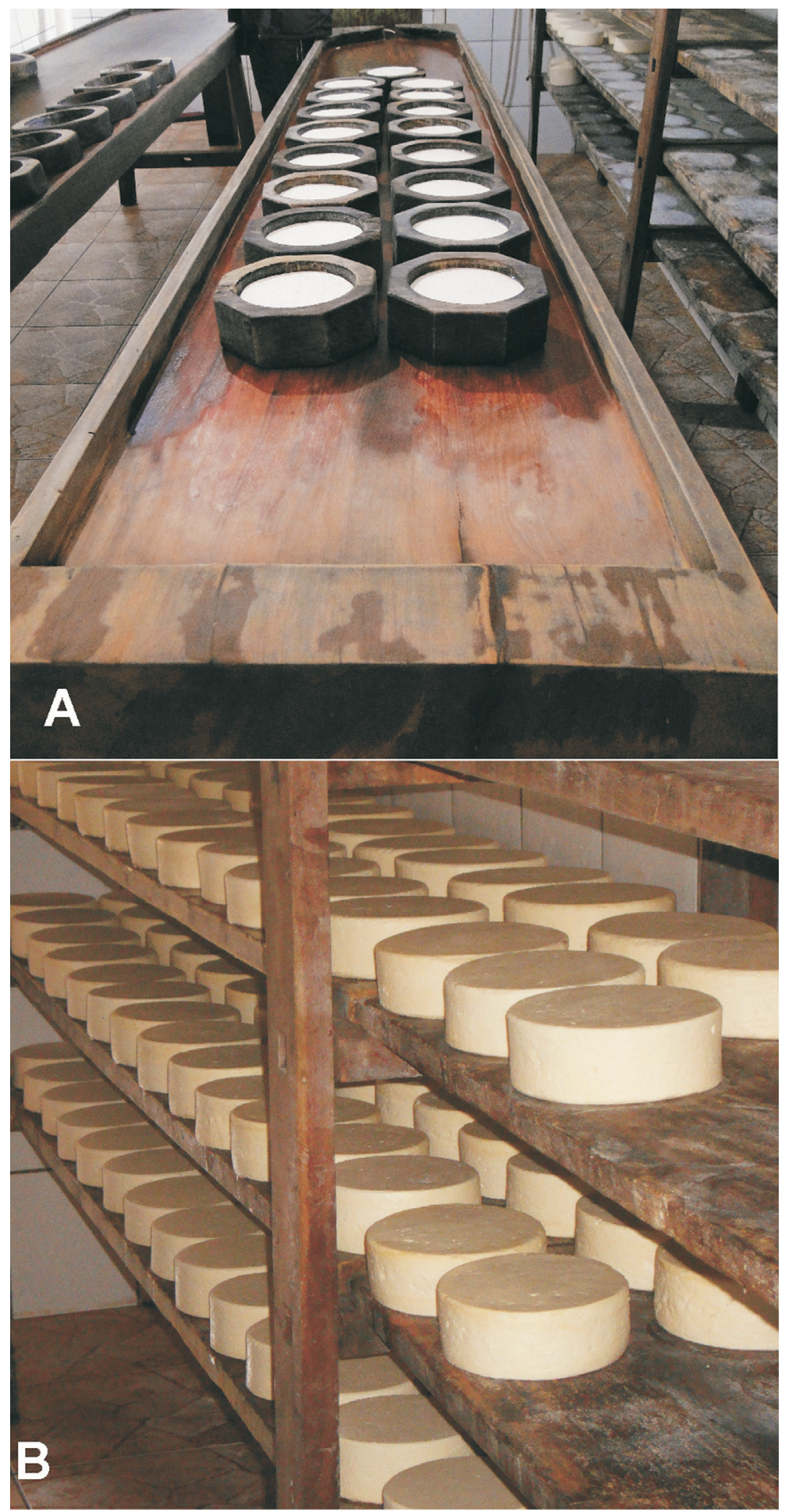

Figure 1 - Wooden table and forms from Serro (A), wooden shelves from Serro (B).

were grown anaerobically in MRS agar (Difco, Lawrence, Kansas, USA; De Man et al., 1960) and Lactococcus spp. aerobically in M17 agar (Difco, Lawrence, Kansas, USA; Terzaghi and Sandine, 1975) both incubated at $30{ }^{\circ} \mathrm{C}$ for 48 h. S. aureus, E. coli and coliforms were evaluated in specific Petrifilm ${ }^{\circledR}$ plates (3M, St. Paul, Minnesota, USA; 3M,
2013) and incubated following the manufacturer's protocol. The microbiological evaluation was done in cheeses after ripening for 17 days for Serro region (Martins, 2006) and 22 days for Canastra region (Dores, 2007). All plating was performed in duplicate. To check for the presence of Salmonella sp. and Listeria monocytogenes in 
cheeses ripened for the time periods mentioned above, we used Reveal ${ }^{\circledR}$ kits (Neogen, Lesher Place Lansing, Miami, USA), following the manufacturer's protocol, which involves a pre-enrichment step before testing. The microbial counts were evaluated by the method of descriptive statistics.

\section{$\mathrm{pH}$ and moisture measurement}

The $\mathrm{pH}$ of $\mathrm{EC}$ and of ripened cheeses was measured using specific $\mathrm{pH}$ meters. The moisture content of the ripened cheeses was determined according to International Dairy Federation - IDF (IDF, 1982).

\section{Scanning electron microscopy}

Fragments of wooden utensils ( $10 \times 3 \times 1 \mathrm{~mm}$ approximately) were obtained for scanning electron microscopy (SEM). Samples from all utensils were fixed in a solution 1:1 (v/v) 4\% glutaraldehyde and 4\% paraformaldehyde (Karnovsky, 1985) for $12 \mathrm{~h}$. The samples were then rinsed with sodium cacodylate buffer for $12 \mathrm{~h}$ and dehydrated in serial ethanol baths $(30,50,70,80,95,100,100$ and $100 \%)$ for $10 \mathrm{~min}$ at room temperature. After dehydration, the samples were dried in a critical point dryer with $\mathrm{CO}_{2}$ (Bal-Tec, Model CPD030, England) and coated with gold for $2 \mathrm{~min}$ in a cathode vacuum evaporator (Balzers, Model FDU010, Germany). Observations of samples were made using a LEO1430 scanning electron microscope (Model VP, England) at an accelerating voltage of $20 \mathrm{kV}$.

\section{Results}

\section{Count groups related to the microbiota of artisanal Minas cheese}

The mean counts of total aerobic mesophiles, yeasts, mesophilic Lactobacillus spp. and Lactococcus spp. in samples from Serro and Canastra regions are shown in Table 1. The aerobic mesophilic counts in the milk samples of Serro and two from Canastra were above the current legislation (> $5 \log \mathrm{cfu} / \mathrm{mL}$; Minas Gerais, 2002b). In the region of Serro, the values obtained for aerobic mesophiles on wooden utensils ranged from $0.96 \log \mathrm{cfu} / \mathrm{cm}^{2}$ in the form and $6.24 \log \mathrm{cfu} / \mathrm{cm}^{2}$ in the shelf. In Canastra, the lowest and highest values of aerobic mesophiles observed on wooden surfaces were 3.5 and $6.24 \log \mathrm{cfu} / \mathrm{cm}^{2}$ in tables; 4.2 and $4.87 \log \mathrm{cfu} / \mathrm{cm}^{2}$ in shelves. The variation in yeast count observed in Canastra was $2.46 \mathrm{log} \mathrm{cfu} / \mathrm{mL}$ in milk and $5.93 \mathrm{log} \mathrm{cfu} / \mathrm{g}$ on cheese. In Serro, the highest yeast count was observed on cheese $(5.05 \mathrm{log} \mathrm{cfu} / \mathrm{g})$ and the lowest on wooden form biofilm $\left(1 \mathrm{cfu} / \mathrm{cm}^{2}\right)$.

\section{Enumeration of pathogens in artisanal Minas cheese and wooden utensils}

The mean counts of pathogens in samples from Serro and Serra da Canastra are shown in Table 1. The counts of $S$. aureus in all samples of ripened cheese from Canastra and two from Serro were below the maximum legal limit ( $\leq 2 \log \mathrm{cfu} / \mathrm{g}$; Minas Gerais, 2002b). However, counts of this pathogen in two milk samples from each region were above the current standard. The ripened cheese counts from Serro were also safe for $E$. coli and coliforms ( $\leq 2$ and $\leq 2.7$ $\log \mathrm{cfu} / \mathrm{g}$, respectively). In Canastra, only one cheese had safe counts of these contaminants. Only one milk sample from Serro showed high E. coli counts (>3.5 $\log \mathrm{cfu} / \mathrm{mL})$, whereas milk samples from Canastra exhibited safe levels of this pathogen $(\leq 2 \log \mathrm{cfu} / \mathrm{mL})$. The current legislation does not define the limit of milk coliforms and therefore, we established the value of $500 \mathrm{cfu} / \mathrm{mL}(2.7 \mathrm{log} \mathrm{cfu} / \mathrm{mL})$, representing half of what is proposed for coliforms in cheese. Thus, one milk sample from Canastra and two from Serro were contaminated by coliforms above $3.6 \mathrm{log}$ $\mathrm{cfu} / \mathrm{mL}$. As there is no legislation establishing limits of microbial indicators of safety for the EC used in the manufacture of artisanal Minas cheese, the same standards for milk were adopted, considering low contamination values $\leq$ $2 \log \mathrm{cfu} / \mathrm{mL}$ for $S$. aureus and E. coli and $\leq 2.7 \log \mathrm{cfu} / \mathrm{mL}$ for coliforms. This way, only one EC sample from Canastra did not have safe levels. In Serro one EC sample exhibited $2.7 \log \mathrm{cfu} / \mathrm{mL}$ for $S$. aureus; two were higher than $2.6 \log$ $\mathrm{cfu} / \mathrm{mL}$ for $E$. coli, and one higher than $2.8 \mathrm{log} \mathrm{cfu} / \mathrm{mL}$ for coliforms. For wooden surfaces, we proposed the limit for S. aureus and E. coli as 20 times lower $\left(5 \mathrm{cfu} / \mathrm{cm}^{2}\right.$ or $0.7 \log$ $\mathrm{cfu} / \mathrm{cm}^{2}$ ) than that established by law for artisanal Minas cheese. In addition, the proposed value corresponds to that 10 times lower than the one the World Health Organization recommends for aerobic mesophiles on surfaces (Silva Jr., 2001). To be less related to pathogens we suggested the limit for coliforms on the wooden surfaces five times the limit proposed for $E$. coli $\left(25 \mathrm{cfu} / \mathrm{cm}^{2}\right.$ or $\left.1.4 \log \mathrm{cfu} / \mathrm{cm}^{2}\right)$. The wooden forms from Serro had low counts of $E$. coli and coliforms; only one showed $1.14 \log \mathrm{cfu} / \mathrm{cm}^{2}$ for $S$. aureus. All tables from Serro had low counts for contaminants evaluated. In Canastra, a table had counts lower than that proposed for S. aureus and E. coli, while two of them had low counts of coliforms. Only one shelf from Serro had above-limit counts for coliforms while the other ones had no coliforms. In Canastra, two shelves were contaminated with S. aureus and one with E. coli. There was no Salmonella sp. or Listeria monocytogenes in samples of ripened cheese from both regions.

\section{$\mathrm{pH}$ and moisture of the cheese}

The $\mathrm{pH}$ ranged from 4.58 to 4.77 and 4.57 to 4.88 for Serro and Canastra ripened cheeses, respectively. The $\mathrm{pH}$ of EC samples ranged from 4.41 to 4.74 in Serro and 5.53 to 5.67 in Canastra. The moisture content of the cheese samples from both regions after the ripening period of 17 and 22 days for Serro and Canastra, respectively, were below the $45.9 \%$ specified by legislation (Minas Gerais, 2008), averaging $37.3 \%$ in Canastra region and $37.4 \%$ in Serro region. 
Table 1 - $\log _{10}$ counts (mean \pm SD) of microorganisms involved in the safety and ripening of artisanal Minas cheese made in Serro and Serra da Canastra regions.

\begin{tabular}{|c|c|c|c|c|c|c|c|}
\hline \multirow[t]{2}{*}{ Microorganisms } & \multirow[t]{2}{*}{ Regions } & \multicolumn{2}{|c|}{$\mathrm{cfu} / \mathrm{mL}$} & \multicolumn{3}{|c|}{$\mathrm{cfu} / \mathrm{cm}^{2}$} & \multirow{2}{*}{$\begin{array}{c}\text { cfu/g } \\
\text { Cheese }\end{array}$} \\
\hline & & Milk & $\mathrm{EC}$ & Form & Table & Shelf & \\
\hline \multirow[t]{3}{*}{ Aerobic mesophiles } & Serro & $6.64 \pm 0.44$ & $7.48 \pm 0.82$ & $2.52 \pm 1.44$ & $4.29 \pm 1.31$ & $4.69 \pm 1.38$ & $8.00 \pm 0.51$ \\
\hline & Canastra & $6.23 \pm 1.27$ & $5.81 \pm 0.50$ & & $4.58 \pm 1.46$ & $4.56 \pm 0.34$ & $8.18 \pm 0.53$ \\
\hline & Legislation & $\leq 5.00$ & & & & & \\
\hline \multirow[t]{2}{*}{ Yeasts } & Serro & $3.13 \pm 1.18$ & $4.48 \pm 0.32$ & $1.03 \pm 1.39$ & $2.98 \pm 0.23$ & $3.21 \pm 0.39$ & $5.00 \pm 0.03$ \\
\hline & Canastra & $3.93 \pm 1.54$ & $3.85 \pm 0.48$ & & $3.27 \pm 0.21$ & $3.25 \pm 0.65$ & $5.21 \pm 0.63$ \\
\hline \multirow[t]{2}{*}{ Lactobacillus spp. } & Serro & $4.57 \pm 0.46$ & $6.92 \pm 1.14$ & $2.59 \pm 1.20$ & $4.01 \pm 0.52$ & $3.99 \pm 0.42$ & $8.00 \pm 0.40$ \\
\hline & Canastra & $5.65 \pm 1.33$ & $5.42 \pm 0.50$ & & $4.26 \pm 1.01$ & $4.35 \pm 0.57$ & $8.21 \pm 0.33$ \\
\hline \multirow[t]{2}{*}{ Lactococcus spp. } & Serro & $6.02 \pm 0.44$ & $7.50 \pm 0.56$ & $2.27 \pm 1.71$ & $4.58 \pm 0.69$ & $4.68 \pm 1.07$ & $8.20 \pm 0.49$ \\
\hline & Canastra & $6.31 \pm 1.38$ & $5.86 \pm 0.39$ & & $4.39 \pm 1.14$ & $4.53 \pm 0.35$ & $8.09 \pm 0.27$ \\
\hline \multirow[t]{3}{*}{ Staphylococcus aureus } & Serro & $2.25 \pm 2.00$ & $0.90 \pm 1.56$ & $0.38 \pm 0.66$ & $0.15 \pm 0.15$ & $0.16 \pm 0.28$ & $2.10 \pm 1.24$ \\
\hline & Canastra & $2.48 \pm 1.68$ & $1.59 \pm 0.36$ & & $0.73 \pm 0.68$ & $0.85 \pm 0.73$ & $0.95 \pm 0$ \\
\hline & Legislation & $\leq 2.00$ & & & & & $\leq 2.00$ \\
\hline \multirow[t]{3}{*}{ Escherichia coli } & Serro & 1.701 .58 & $1.93 \pm 1.69$ & $0 \pm 0$ & $0.07 \pm 0.12$ & $0.27 \pm 0.47$ & $1.30 \pm 0.33$ \\
\hline & Canastra & $1.13 \pm 0.31$ & $0.97 \pm 0.03$ & & $0.74 \pm 1.29$ & $0.47 \pm 0.45$ & $3.10 \pm 1.02$ \\
\hline & Legislation & $\leq 2.00$ & & & & & $\leq 2.00$ \\
\hline \multirow[t]{3}{*}{ Coliforms } & Serro & $3.08 \pm 1.53$ & $1.83 \pm 1.59$ & $0 \pm 0$ & $0.33 \pm 0.30$ & $0.66 \pm 1.14$ & $1.50 \pm 0.70$ \\
\hline & Canastra & $2.53 \pm 0.98$ & $1.57 \pm 1.03$ & & $2.23 \pm 1.23$ & $1.17 \pm 0.12$ & $3.71 \pm 1.02$ \\
\hline & Legislation & & & & & & $\leq 3.00$ \\
\hline
\end{tabular}

\section{Ultra structure of the biofilm from utensils}

The electron micrographs showed that surfaces of the utensils were almost completely covered by a diversified ecosystem consisting of cocci, bacilli, yeasts and filamentous fungi (Figure 2). Tables from both regions showed a diversity of microorganisms, although filamentous fungi were observed more frequently on the samples from Serro and rarely on those from Canastra. Cocci were the predominant shape observed in all wooden utensils from both regions. Moreover, bacilli were seen more frequently on utensils from Serro region than those from Canastra. It is suggested the presence of exopolysaccharides where the cocci are inserted (Figure 2D).

\section{Discussion}

This study describes for the first time the microorganisms in biofilms of wooden utensils involved in the safety of artisanal Minas cheese as well as those responsible for its ripening. And yet, this work assessed for the first time the ultra structure of these biofilms.

The high count of aerobic mesophiles in milk and EC samples may be related to the corresponding numbers of mesophilic lactobacilli and lactococci in these raw materials. The counting of aerobic mesophiles on the surfaces of tables and shelves from the two regions confirms the existence of a biofilm with diverse microbiota, as observed by
Lortal et al. (2009) in biofilm formed on wooden vats used in the manufacturing of Ragusano cheese.

Yeasts present in biofilms can act in two ways in artisanal cheese. Firstly, they may cause spoilage of the product, resulting in an undesirable flavor, discoloration, gas production and changes in texture (Fleet, 1990). However, they may exert beneficial effects through proteolytic and lipolytic activities, leading to the formation of flavor during ripening (De Freitas et al., 2009; Fadda et al., 2004). Borelli et al. (2006) obtained yeast counts above 7 log cfu/g in cheese from Canastra after five days of ripening and among the several species present, the main were Candida catenulata, Debaryomyces hansenii, Torulaspora delbrueckii and Kluyveromyces lactis. This last one is able to assimilate and ferment lactose (Fleet, 1990) and thus, should be involved synergistically with LAB during the initial acidification of the cheese. This counting can be related to the insufficient time of ripening for the cheese from Canastra, which at 22 days, comes close to those obtained in our study (5.2 log cfu/g).

Knowing that the $\mathrm{pH}$ influences the adherence capacity of a microorganism (Mafu et al., 2011) and low pH reduces the rate of adherence of $S$. aureus (Zmantar et al., 2010) and E. coli (Mafu et al., 2011), the low counts of all contaminants in all tables from Serro, S. aureus in one table and $E$. coli in two tables from Canastra can be attributed to the acidic condition of the surfaces, whose $\mathrm{pH}$ must be near 

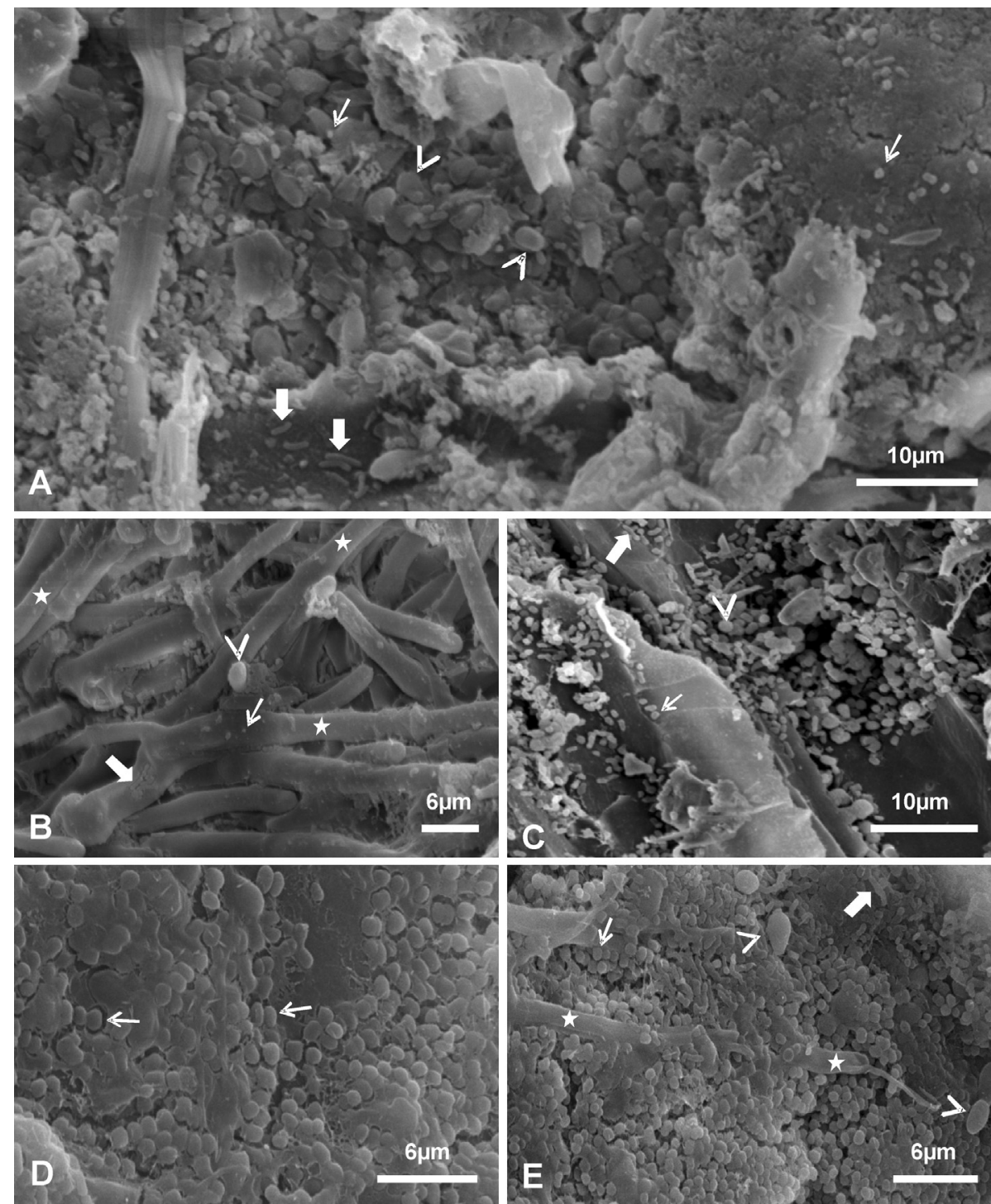

Figure 2 - Scanning electron microscopy of biofilms on wooden utensils from Serro: table (A), form (B) and shelf (C); Canastra: table (D) and shelf (E). Cocci (thin arrows), bacilli (large arrows), yeast (arrowheads) and filamentous fungi (stars).

the average $\mathrm{pH}$ of the EC from Serro (4.54) and Canastra (5.58). In addition, factors such as the production of exopolysaccharides (Kim et al., 2009) and bacteriocins by LAB (González et al., 2007), competition for nutrients and adhesion sites should be considered. According to Carmo et al. (2002), food poisoning caused by $S$. aureus enterotoxins occur when the counts of this microorganism exceeds $6 \log$ $\mathrm{cfu} / \mathrm{g}$ in food. Therefore, it is essential to control this pathogen numbers in utensils and especially raw materials. The counts observed in the milk samples indicate unsatisfactory GMP. Thus, the microbiological quality of milk should receive special attention, since this is the main source of microorganisms that will form biofilms on the utensils and direct their safe use.

Although ripening is known to reduce pathogens, it appears that the processing starting with a microbiological quality raw material favors ripening and keeps pathogen counts below legally safe levels. When the counts of E. coli in milk were compared to those in ripened cheese, it was found that even when milk samples from Canastra had low counts of $E$. coli, two cheeses from this region presented counts ( $>3.3 \log \mathrm{cfu} / \mathrm{g})$ above the safety standards for this pathogen. This indicates that milk contributes to the contamination existing on wooden utensils, and consequently the cheese contamination. High counting of $S$. aureus and coliforms found in two of the Canastra milk samples should have a direct influence on the elevated counting obtained on the utensils. However, $S$. aureus were at low levels $(<1 \log \mathrm{cfu} / \mathrm{g})$ in cheeses from Canastra, while E. coli and coliforms count remained high, suggesting inappropriate cleaning of the shelves. Furthermore, tables from Canastra contained slots across the surface, making it difficult to clean and enabling organic matter accumulation and microbial growth. The cheese makers from Canastra region 
should give a good surface finish of the tables, so that they become as smooth as possible, facilitating cleanup. Therefore, producers in both regions must apply correctly the GMP, avoiding contamination of the milk.

The high counts of mesophilic Lactobacillus spp. and Lactococcus spp. in biofilms on tables and shelves from both regions are desirable, since these microorganisms can be released from the biofilm and join those existing in milk (Lortal et al., 2009) and the EC that will be used for the next batch. LAB are responsible for producing the ripened cheese flavor (Awad et al., 2007; Randazzo et al., 2010) by the acidification and production of antimicrobial compounds (Kim et al., 2009; Settanni et al., 2011), which inhibit the growth of pathogens and control the multiplication of spoilage and contaminating microorganisms.

The variability of shapes observed by SEM may be related to the various methods of cleaning used by cheese makers in each region. Although this work was not done to quantify filamentous fungi in biofilms, they were nonetheless observed in the micrographs of some tables and shelves from the two regions and forms from Serro (Figure 2B), showing the diversity of microorganisms that may constitute these biofilms. The lower microbial counts obtained in a few utensils alone do not indicate the formation of a biofilm. However, micrographs showed the presence of such a structure with microorganisms adhered to the surfaces.

To sum up, the results of this study suggest that wooden utensils could continue to be used, as long as the cheese makers do their cleaning properly, especially those of the Serra da Canastra, due to surface irregularities. It is important to emphasize here that milk should be at lower degree of contamination, which would favor the ripening of cheese, guaranteeing the consumer a safe product and maintaining its traditional sensory characteristics. More studies should be done to verify the complete microbiota existing in these biofilms, and thus understand the role of each microorganism in the process of ripening and safety of artisanal Minas cheese.

\section{Acknowledgments}

We thank CAPES and CNPq for financial support, as well as the Core for Microscopy and Microanalysis of UFV. The authors would like to thank the cheese makers for providing the samples.

\section{References}

APHA (2001) Compendium of Methods for the Microbiological Examination of Foods. 4th ed. American Public Health Association, Washington, D.C.

Awad S, Ahmed N, El Soda M (2007) Evaluation of isolated starter lactic acid bacteria in Ras cheese ripening and flavour development. Food Chem 104:1192-1199.

Beuchat LR, Golden DA (1989) Antimicrobials occurring naturally in foods. Food Technol 43:134-142.
Borelli BM, Ferreira EG, Lacerda ICA, Franco GR, Rosa CA (2006) Yeast populations associated with the artisanal cheese produced in the region of Serra da Canastra, Brazil. World J Microb Biot 22:1115-1119.

Brown AD (1976) Microbial water stress. Bacteriol Rev 40:803846.

Capdeville I, Nguyen KM (1990) Kinetics and modelling of aerobic and anaerobic film growth. Water Sci Technol 22:149170.

Carmo LS, Dias RS, Linardi VR, Sena MJ, Santos DA, Faria ME, Pena EC, Jett M, Heneine LG (2002) Food poisoning due to enterotoxigenic strains of Staphylococcus present in Minas cheese and raw milk in Brazil. Food Microbiol 19:9-14.

Casalta E, Sorba J-M, Aigle M, Ogier J-C (2009) Diversity and dynamics of the microbial community during the manufacture of Calenzana, an artisanal Corsican cheese. Int J Food Microbiol 133:243-251.

Crow VL, Coolbear T, Gopal PK, Martley FG, McKay LL, Riepe $\mathrm{H}$ (1995) The role of autolysis of lactic acid bacteria in the ripening of cheese. Int Dairy J 5:855-875.

De Freitas I, Pinon N, Maubois J-L, Lortal S, Thierry A (2009) The addition of a cocktail of yeast species to Cantalet cheese changes bacterial survival and enhances aroma compound formation. Int J Food Microbiol 129:37-42.

De Man JC, Rogosa M, Sharpe ME (1960) A medium for the cultivation of lactobacilli. J Applied Bacteriol 23:130-135.

Del Campo G, Santos JL, Berregi I, Velasco S, Ibarburu I, Dueñas MT, Irastorza A (2003) Ciders produced by two types of presses and fermented in stainless steel and wooden vats. J Inst Brewing 109:342-348.

Dores MT (2007) Queijo Minas Artesanal Maturado à Temperatura Ambiente e sob Refrigeração. Viçosa, Brasil, 78 p. (M. Sc. Dissertation, Departamento de Tecnologia de Alimentos, UFV).

EMATER - Empresa de Assistência Técnica e Extensão Rural do Estado de Minas Gerais (2004) Queijo Minas Artesanal: Tradição e qualidade que revelam Minas. Revista da EMATER 80:8-9.

Fadda ME, Mossa V, Pisano MB, Delphano M, Cosentino S (2004) Occurrence and characterization of yeast isolated from artisanal Fiore Sardo cheese. Int J Food Microbiol 95:51-59.

Fleet GH (1990) Yeasts in dairy products. J Applied Bacteriol 68:199-211.

González L, Sandoval H, Sacristán N, Castro JM, Fresno JM, Tornadijo ME (2007) Identification of lactic acid bacteria isolated from Genestoso cheese throughout ripening and study of their antimicrobial activity. Food Control 18:716-722.

IDF (1982) Cheese and processed cheese - Total solid content. IDF standard 4A. Brussels, Belgium: International Dairy Federation.

Karnovsky MJ (1965) A formaldehyde-glutaraldehyde fixative of high osmolarity for use in electron microscopy. J Cell Biol 27:137A.

Kim Y, Oh S, Kim SH (2009) Released exopolysaccharide (r-EPS) produced from probiotic bacteria reduce formation of enterohemorrhagic Escherichia coli O157:H7. Biochem Bioph Res Com 379:324-329.

Licitra G, Ogier JC, Parayre S, Pediliggieri C, Carnemolla TM, Falentin H, Madec MN, Carpino S, Lortal S (2007) Variabil- 
ity of bacterial biofilms of the "Tina" wood vats used in the Ragusano cheese-making process. Applied Env Microbiol 73:6980-6987.

Lortal S, Di Blasi A, Madec MN, Pediliggieri C, Tuminello L, Tanguy G, Fauquant J, Lecuona Y, Campo P, Carpino S, Licitra G (2009) Tina wooden vat biofilm: A safe and highly efficient lactic acid bacteria delivering system in PDO Ragusano cheese making. Int J Food Microbiol 132:1-8.

Mafu AA, Plumety C, Deschênes L, Goulet J (2011) Adhesion of pathogenic bacteria to food contact surfaces: Influence of $\mathrm{pH}$ of culture. Int J Microbiol 2011:1-9.

Mariani C, Briandet R, Chamba J-F, Notz E, Carnet-Pantiez A, Eyoug RN, Oulahal N (2007) Biofilm ecology of wooden shelves used in ripening the French raw milk smear cheese Reblochon de Savoie. J Dairy Sci 90:1653-1661.

Martins JM (2006) Características físico-químicas e microbiológicas durante a maturação do queijo Minas artesanal da região do Serro. Viçosa, Brasil, 146 p. (D. Sc. Thesis, Departamento de Tecnologia de Alimentos, UFV).

Minas Gerais (a). Portaria no 518, de 14 de junho de 2002. Dispõe sobre requisitos básicos das instalações, materiais e equipamentos para a fabricação de queijo minas artesanal. Available at: http://www.ima.mg.gov.br/component/search/?searchword=portaria $+518 \&$ ordering $=\&$ search phrase $=$ all. Accessed 04 July 2011.

Minas Gerais (b). Lei 14.185, de 31 de janeiro de 2002. Dispõe sobre o processo de produção de queijo Minas artesanal. Available http:/hera.almg.gov.br/cgi-bin/nph-brs?co1=e\&d=NJMG $\& p$ $1 \& \mathrm{u}=\mathrm{http}: / /$ www.almg.gov.br/njmg/chama pesquisa.asp\& SECT $1=$ IMAGE $\&$ SECT $2=$ THESOFF $\&$ SECT $3=$ PLUROF F\&SECT6=HITIMG\&SECT7=LINKON\&1 $=20 \& \mathrm{r}=$ $1 \& \mathrm{f}=\mathrm{G} \& \mathrm{~s} 1=\mathrm{DECRETO}$ 42645 2002.NORM.\&SECT8=SOTEXTO. Accessed 04 July 2011.
Minas Gerais. Decreto $\mathrm{n}^{\mathrm{o}} 44.864$, de $1^{\circ}$ de agosto de 2008. Altera o Regulamento da Lei ${ }^{\circ} 14.185$, de 31 de janeiro de 2002, que dispõe sobre o processo de produção de Queijo Minas Artesanal. Available at: http://imanet.ima.mg.gov.br/nova/gce/outros documentos/ Decreto_44864.pdf. Accessed 04 July 2011.

Randazzo CL, Pitino I, Ribbera A, Caggia C (2010) Pecorino Crotonese cheese: Study of bacterial population and flavour compounds. Food Microbiol 27:363-374.

Settanni L, Franciosi E, Cavazza A, Cocconcelli PS, Poznanski E (2011) Extension of Tosèla cheese shelf-life using nonstarter lactic acid bacteria. Food Microbiol 28:883-890.

Silva Jr. EA (2001) Manual de controle higiênico-sanitário em alimentos. Varela, São Paulo.

Solieri L, Giudici P (2008) Yeasts associated with traditional balsamic vinegar: Ecological and technological features. Int $\mathrm{J}$ Food Microbiol 125:36-45.

Terzaghi BE, Sandine WE (1975) Improved medium for lactic streptococci and their bacteriophages. Applied Env Microbiol 29:807-813.

Trulear MG, Characklis WG (1982) Dymanics of biofilm processes. J Water Pollut Control Fed 54:1288-1301.

Zmantar T, Kouidhi B, Miladi H, Mahdouani K, Bakhrouf A (2010) A microtiter plate assay for Staphylococcus aureus biofilm quantification at various $\mathrm{pH}$ levels and hydrogen peroxide supplementation. New Microbiol 33:137-145.

3M Petrifilm (2013) Protocol for enumeration of E. coli and coliforms according to AOAC 986.33 and 989.10. Available at: http://multimedia.3m.com $/ \mathrm{mws} /$ mediawebserver?mwsId=SSSSSu7zK1fs 1xtUnYtB58 1ev7qe17zHvTSevTSeSSSSSS-. Accessed 15 May 2013

All the content of the journal, except where otherwise noted, is licensed under a Creative Commons License CC BY-NC. 